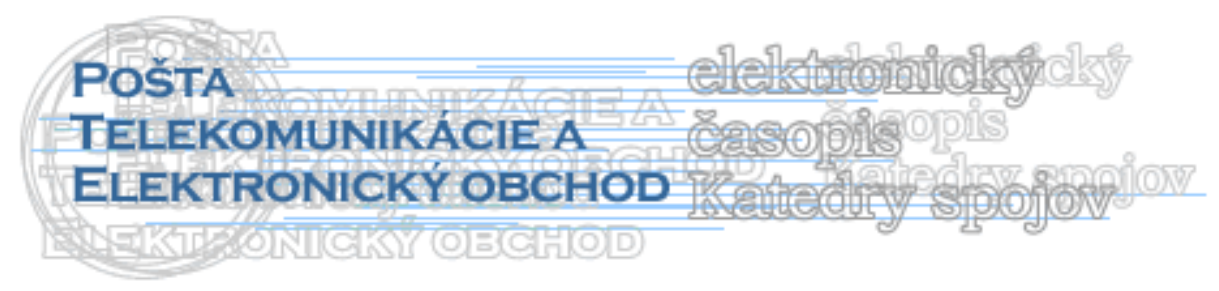

\title{
FUNCTIONING OF POLISH POSTAL SERVICES MARKET DURING THE FINANCIAL CRISIS
}

\author{
Pawel Mrowiec PhD ${ }^{1}$
}

\begin{abstract}
Summary
Since Poland joined the European Union, the market of postal services has been gradually adapted as well as liberalized in accordance with EU requirements. The liberalization process means that the scope of services restricted for the public operator has been reduced and the number of other postal operators has increased. The current economic crisis has had a considerable impact on the postal services market what can be proved by recent financial reports published by Poczta Polska S.A. (The Polish Postal Service) - the public operator. It also seems that despite major organizational changes made in Poczta Polska S.A., the direction of these changes does not always improve the quality of postal services. The aim of the present article is presentation of selected issues related to the functioning of Polish market of postal services during current financial crisis.
\end{abstract}

\section{Keywords}

postal services, public services, financial crisis

\section{Introduction}

After Poland joined the EU its market for postal services became more liberal. Although legal regulations for rendering these services changed ${ }^{2}$, we cannot speak of a radical transformation on the Polish postal market. Art. 2. 1 of the new Postal Services Act defines postal services as profit oriented services rendered in local and international turnover, for example:

- Collecting, shipping and delivering mail, parcels and door drops,

- Running retail facilities for collection and exchange of correspondence between entities using these facilities,

- Providing postal orders services

The main postal service operator in Poland is the so called national operator-Poczta Polska S.A. (Polish Postal Service). It is the only entity disposing of sufficient infrastructure to render postal services of universal nature. Universal postal services still constitute the major part of services rendered by Polish Post Service, what can be proved by the company's financial figures for 2010. In this year the operator rendered more than 2,1 billion postal services in local and international turnover (universal postal services, as well as others

\footnotetext{
"Paweł Mrowiec PhD: Chair of Banking and Finance, Department of Finance and Information Technologies, Bielsko-Biała School of Finances and Law, ul. Tańskiego 5, 43-382 Bielsko-Biała, tel. +48 785 584 545, e mail: pawel.mrowiec@onet.eu

${ }^{2}$ Act of 12th June 2003, Postal Law, Journal of laws of 2008, Nr 189, item 1159.
} 
including courier services) what generated nearly PLN 4,9 billion of revenue. The number of universal postal services alone amounted to 1,7 billion and brought almost PLN 4,3 billion in revenue. In 2010 non-public operators delivered more than 3,5 million postal services in local and international turnover (parcels with correspondence, parcels, mail shots, door drops) and generated more than PLN 1,3 billion of revenue ${ }^{3}$.

The above mentioned figures show that the Polish market of postal services is still dominated by the national operator, who:

- has to adjust to radically changed legal regulations,

- is currently functioning in financial crisis conditions.

The impact of the above mentioned factors will be the subject to financial analysis in Poczta Polska S.A. for the period of 2007-2010.

\section{Financial situation of Polish Postal Service between 2007 and 2010}

Polish Postal Service is the national operator with the biggest market share in postal services. The operations of public postal operator are extremely important for a country's economy. In most countries its functioning is seen as a service of public utility character and an important place in the hierarchy of its objectives is occupied by universal services. In the market-driven model of economy there is, however, a necessity to fulfil certain commercial criteria and achieve certain financial aims. Coming up to the above mentioned requirements creates special conditions for functioning of public postal operators ${ }^{4}$.

Selected financial data of Poczta Polska S.A. for the years 2007-2010 are shown in table 1.

Tab. 1. Selected financial data of Poczta Polska S.A. for the years 2007-2010 (in million of PLN).

\begin{tabular}{|l|r|r|r|r|}
\hline \multicolumn{1}{|c|}{ Specifications } & \multicolumn{1}{c|}{$\mathbf{2 0 0 7}$} & $\mathbf{2 0 0 8}$ & $\mathbf{2 0 0 9}$ & $\mathbf{2 0 1 0}$ \\
\hline Assets in total, inclusive of: & $5.354,2$ & $4.691,7$ & $5.026,7$ & $4.628,4$ \\
-fixed assets & $2.583,6$ & $2.649,7$ & $2.476,1$ & $2.396,3$ \\
-current assets & $2.770,6$ & $2.042,0$ & $2.550,5$ & $2.232,0$ \\
\hline Equity & $1.646,7$ & $1.430,4$ & $1.238,3$ & $1.281,9$ \\
Liabilities and accruals for liabilities, inclusive of : & $3.707,5$ & $3.261,3$ & $3.788,4$ & $3.346,4$ \\
-short term liabilities and accruals & $2.829,5$ & $2.295,2$ & $2.545,5$ & $2.179,5$ \\
\hline Revenue from sales & $6.518,3$ & $6.755,4$ & $2.233,3$ & $6.434,0$ \\
Financial result from sales & $+124,3$ & $-291,3$ & 476,6 & $1.091,7$ \\
Net financial result & $+61,4$ & $-215,3$ & 32,8 & 52,1 \\
\hline Net cash flows in total, inclusive of: & $+818,0$ & $-810,5$ & 889,4 & $-407,9$ \\
- operational activity & & & & \\
- investment activity & $+1.293,4$ & $-605,0$ & 936,0 & $-280,2$ \\
- financial activity & $-434,0$ & $-178,7$ & $-22,8$ & $-95,3$ \\
& $-41,4$ & $-26,8$ & $-23,8$ & $-32,4$ \\
\hline
\end{tabular}

Source: own work based on financial statements of public operator for the period of 2007-2010, http://www.poczta-polska.pl/O_Firmie/Sprawozdaniafinansowe/.

Total assets of Poczta Polska S.A. in 2007 -2010 decreased by PLN 725 million, and showed a continuous down trend of equity, from PLN 1.646 million to PLN 1.281 million. What is also worrying is falling level of revenue from sales although in 2010 Poczta Polska S.A. reached a record breaking financial result with sales on the level of PLN 1.091 million. When we analyze net cash flows for $2007-2010$ we can notice that they fell from PLN 818 million in 2007 to negative value of minus PLN 407 million in 2010.

\footnotetext{
${ }^{3}$ Report of Office of Electronic Communication (UKE) president on the condition of postal services market in 2010, Warszawa 2011, p. 3-4

${ }^{4}$ See A. Panasiuk, Usługi pocztowe. Rynek i marketing, PWN, Warszawa 2003, p. 17 -21.
} 
Profitability of Poczta Polska S.A. in 2010 was on a very low level but still the national operator has a serious advantage over all other competitors - it is the national network of post offices reaching all clients in the whole country. At the end of 2009 Poczta Polska S.A. disposed of three times as many retail outlets as all non-public operators. The vast post offices network means, however, extremely high maintenance costs. According to figures from 2009 Poczta Polska S.A. had almost 48,000 of outboxes in use, out of which $2 / 3$ served small towns and villages. Postal services were offered in 8,300 retail facilities while about 1,000 of them were loss making. The analyses proved that $80 \%$ of profit made by Poczta Polska S.A. is generated by post offices located in 15 biggest cities in Poland and more than $90 \%$ of facilities located in rural areas are unprofitable. The results quoted above forced the Polish national operator to reorganize its network of retail outlets - to close down the loss-making points and re-open them on agency bases. It is estimated that the costs of functioning of an agency are about $30 \%$ lower than costs of running a regular post office facility ${ }^{5}$.

\section{The directions for development of Poczta Polska S.A. in the context of financial crisis}

The present financial crisis (sometimes referred to as American crisis) started, as many experts assume, on 15th September 2008 with the collapse of Lehman Brothers, a 158-yearold investment bank. However, real problems of American financial institutions began a couple of months earlier ${ }^{6}$.

The impact of American crisis on Polish economy is tangible, though Polish public authorities made a lot of efforts to alleviate the negative effects of recession. Among such initiatives were: the Package of Trust prepared by Polish National Bank, increased deposit guarantees, increased guarantee limits and sureties of the State Treasury.

Poczta Polska S.A. was also hit by the effects of financial crisis what is clearly visible in the financial analysis presented above. In the years 2007-2010 the revenue from sales went considerably down.

The new strategy of Poczta Polska S.A. includes five directions of activities based on:

- modernity - reorganization of management style, implementation of concept of optimized process management, generating new ideas and rendering services based on new technologies,

- efficiency - which implies the need for optimization of resources and organizational structure of Poczta Polska S.A.,

- customer-oriented approach - building a relationship with customer and creating positive image of the company,

- responsibility - determination of the management board in implementation of the new strategy and in delegating and carrying out responsibility for the results on each level of the organization,

- commitment of all employees in carrying out the activities aimed at improving the condition of the national operator.

The most important tasks to complete along with costs reduction and control, are: defence of the position of the market leader, search for new sources of revenue and improvement of the quality of services including the timeliness of deliveries. It has also been assumed that as the result of the applied strategy Poczta Polska S.A. will hold the position of first-class mail market leader, will increase revenue from financial services and will enlarge its share on the

\footnotetext{
${ }^{5}$ M. Papiernik -Wojdera, A. Matuszewska -Pierzynka, Rynek usług pocztowych w Polsce u progu jego pełnej liberalizacji, Acta Universitatis Lodziensis, 2011, p. 46.

${ }^{6}$ Bear Stearns was taken over by JPMorgan Chase, and Merrill Lynch by Bank of America.
} 
logistic services market ${ }^{7}$.

The quality of services offered by Poczta Polska S.A. equals, most of all, the timeliness of delivering mail and parcels ${ }^{8}$ :

- 2008 - 2,481 complaints for delayed delivery, of which: 1,026 concerned regular mail delivery, 497 complaints concerned first class post, and 529 concerned economic post,

- 2009 - 845 complaints for delayed delivery, of which: 407 concerned regular mail delivery, 194 complaints concerned first class post, and 213 concerned economic post

- 2010 - 499 complaints for delayed delivery were made and processed in accordance with article 48a of Postal Services Act (267 complaints concerned first class post, 232 complaints concerned economic post).

The strategy of Poczta Polska S.A. also assumes diversification of sales revenue sources within capital group. The capital group of Poczta Polska S.A. consists of the following entities ${ }^{9}$ :

- Postal Bank - founded in 1990 as a typical accounting bank enabling easy and fast mass payment service,

- Open Pension Fund 'Pocztylion',

- Postal Agency of Financial Services - a partnership founded in 2000 offering financial products: life insurance, property insurance, agricultural insurance and bank products,

- Post Media Service - a partnership offering promotional and advertising services supporting the sales of Poczta Polska S.A. products

- Postdata - offering IT support for more than 7,300 post retail facilities,

- Mutual Insurance Post Company - offering insurance products,

- Poczta Polska S.A. Digital Services - a partnership offering electronic and new technology services. The continuous trend of falling volumes of traditional mail on Polish and international postal markets was an impulse for diversifying of Poczta Polska S.A. product portfolio and adding to it electronic service sector related to communications and correspondence.

\section{Summary}

The current financial crisis exerted a considerable influence over the operations and financial results of Polish national postal operator Poczta Polska S.A. Although the company enjoys the biggest market share and renders so called universal services, the demand for postal services has decreased what resulted in major drop in sales revenue. An important direction for future functioning of Poczta Polska S.A. is enlarging its product and service portfolio which will diversify the sales revenue sources. It is still unsure, however, whether the newly opened areas of activity will add to increased profitability of the whole organization.

\section{Literature}

[1] Ustawa z dnia 12 czerwca 2003 roku Prawo pocztowe, Dz. U. z 2008 roku, Nr 189, poz. 1159

\footnotetext{
${ }^{77}$ M. Papiernik -Wojdera, A. Matuszewska -Pierzynka, Rynek usług pocztowych w Polsce u progu jego pełnej liberalizacji, Acta Universitatis Lodziensis, 2011, p. 28.

${ }^{8}$ Report of Supreme Audit Office (NIK), Information on audit results. Commercialization and restructuring of Poczta Polska, Nr 119/2012/P/11/064/KIN

${ }^{9}$ http://www.poczta-polska.pl/O_Firmie/GrupaPP/PPUC.html
} 
[2] Raport Prezesa UKE o stanie rynku usług pocztowych w 2010 roku, Warszawa 2011

[3] Raport NIK, Informacja o wynikach kontroli. Komercjalizacja i restrukturyzacja Poczty Polskiej, Warszawa 2012

[4] A. Panasiuk, Usługi pocztowe. Rynek i marketing, PWN, Warszawa 2003

[5] M. Papiernik -Wojdera, A. Matuszewska -Pierzynka, Rynek usług pocztowych w Polsce u progu jego pełnej liberalizacji, Acta Universitatis Lodziensis, 2011

[6] http://www.poczta-polska.pl

[7] ŠTOFKOVÁ, J a kol.: Financie a finančné riadenie. Žilina : EDIS, 2012. 280 s. ISBN 978-80-554-0169-0 